\title{
Translating the tourist gaze: from heritage and 'culture' to actual encounter
}

\author{
David Katan ${ }^{\mathrm{i}}$ \\ Università del Salento, Lecce (Italia)
}

\begin{abstract}
This paper covers two main areas. The first area is an analysis of the various facets of heritage, cultural tourism and tourist encounter with other cultures in terms of culture-bound tourist gaze, a simplified, generalised and necessarily distorted model of 'the Other'. The model of perception is culture itself, and is discussed in terms of 3 macro levels: heritage; the practices and traditions of a people; and the system of internal values and beliefs that both form the model of reality and guide it. Secondly, the paper focuses on translation and Outsider interpretation. It reveals how little emphasis is given either to translator language or to cultural competence, and focuses on the problems of mediating for the culture-bound tourist gaze.
\end{abstract}

Keywords: heritage, tourism, culture, intercultural communication, translation, Euro-Mediterranean

Título: Trasladar la mirada del turista: del patrimonio cultural al encuentro auténtico

Resumen: Este artículo se focaliza en dos áreas principales. La primera se ocupa de analizar los distintos aspectos del patrimonio, del turismo cultural y del encuentro con otras culturas, en la perspectiva de la mirada 'cultural' del turista, que elabora un modelo simplificado y distorsionado del 'otro'. El modelo perceptivo es la cultura misma, que a continuación se estudia en tres diferentes niveles: el patrimonio; los usos y tradiciones de un pueblo; y, finalmente, el sistema de valores y creencias interiorizadas que conforman la representación de la realidad. En segundo lugar, el trabajo se centra en la traducción y en la interpretación en la perspectiva del 'otro', poniendo de relieve la escasa atención generalmente reservada a las competencias lingüísticas y culturales del traductor, y los problemas que plantea la mediación entre distintas culturas y miradas.

Palabras clave: patrimonio, turismo, cultura, comunicación intercultural, traducción, Euro-Mediterráneo 


\section{Culture and tourism}

The genesis for this paper comes from having taught a module entitled "translation and intercultural communication" on an MA course, entitled the "Euro-Mediterranean Master in Culture and Turism ${ }^{1}$. The course objectives also highlighted heritage activities which we will come to later. The main object of this paper will be to represent an overview of the terms and, indirectly, to provide a framework for how 'culture'and translation should be treated in Tourism Studies.

Interestingly, the "Euro-Mediterranean" area itself is a recently coined geo-political entity, an extension of the European Union, taking in the Middle Eastern and African countries bordering the Mediterranean. Its existence is due to a geo-political strategic drive to promote "a better understanding between cultures" (2005) in what is perhaps the most volatile macro-region in the world. Within its area, of course, are many cultures, civilisations and nation-states. For convenience, national borders are often conflated with cultural borders, but within those homogenising borders will be a host of identifiable different cultural groups, such as ethnic, linguistic, religious and geographical. Many of these cultural groups live as minorities within the homogenising umbrella of 'another's' culture. Plus there are many other, extra-national, cultures such as class, gender, generational, professional, and of course, tourism.

The term 'culture' is without doubt strongly related to tourism, as the eighty-five million plus Google hits testify. The terms are inseparable when it comes to government ministries and municipal offices, university courses and MAs, festivals, conferences and indeed articles - such as this one. Amazon cites at least 21 books with the terms in the title. The terms may be perceived:

1. as separate but linked: e.g. City Tourism \& Culture ETC2; "Tourism and culture: a sustainable partnership";; "MA in Culture and Tourism"4;

2. as one having an impact on the other: e.g. "Case study on the effects of tourism on culture and the environment"5; "The Impact of Culture on Tourism - OECD"6. 3. as one being a quality of the other: e.g. "Isle of Man Tourism Culture"7; "UNESCO: Cultural tourism"8.

Culture then is clearly a flexible and also multi headed thing; and we should also remember that, as individuals, we are members of many cultures. When we function as members of a tourist culture, we are usually visible as such, due to location (hotel, restaurant, sights...); dress (casual); accessories (backpack, water, camera, map ...); lack of local (Insider) knowledge and maybe language; and behaviour (standing rather than walking; gazing, pointing, asking, yawning...). And tourists the world over tend to see the world in similar ways according to a shared map or model of reality, weltanschauung, or world view. By map, I am referring to Korzybski's metaphor (1958: 58-60) of how the mind works, re-presenting the territory. Bandler and Grinder (1975) then explored the idea of the map which necessarily deletes, distorts and generalizes what is 'out there' to provide "a model of reality". Reality is hence filtered according to a universal processes of simplification and standardisation to help individuals orient themselves in the world. This is what Urry and Larsen (2011) have called "the tourist gaze".

So, logically, a tourist-gaze version of a country, people or an area, will tend towards fixed stereotypes, usually helped by well-marketed promotional campaigns. The tourist view of Ireland, for example, is clearly emphasized on the home page of "Visit Ireland", with photographs that continue the self-perpetuating system of gazing at what has already been (re)presented: rolling green countryside, castles and sheep.

Yet, also the model of the foreign culture will also vary according to the domestic culture being targeted, and according to the type of culture being promoted. The Italian "consiglidiviaggio.it" website, for example, written for and by Italians, begins its overview of Malta as being almost Italian(personal translation) ${ }^{10}$ :

Malta is becoming ever more popular as a seaside holiday destination, which you can combine with an English course practically all year round. Italians feel at home on the island because, apart from English and Maltese, they speak our language - and very well too. They watch Italian TV, follow our football championship matches and are fans of our football clubs.

\section{Defining culture}

The term is notoriously difficult to define, being "one of the two or three most complicated words in the English language" (Williams in Jenks, 1993: 1). Originally, culture was simple. It referred exclusively to the Humanist ideal, culture(1), of what was civilized in a developed society (the education system, the arts, architecture). Then a second meaning, culture(2), the way of life of a people, took its place alongside. Emphasis at the time was very much on 'primitive' cultures and tribal practices.

A development of this, culture(3), saw culture as primarily a model of the world, formed through a shared array of value orientations (Kluckhohn / Strodtbeck, 1961) or cultural dimensions (Hofstede, 2001). With the development of Sociology and Cultural Studies a further meaning has emerged, related to forces in society or ideology. Here, culture(4) is a site of conflict for authority or power. When it is acquired, it is through the subliminal and enforced norms of, for example, capitalist and colonialist action.

Hence the "cultural tourist", who travels "with the intention to gather new information and experiences to satisfy... cultural needs" (Richards, 1996: 24) may do so in at least four different ways, according to which aspect of 'culture' is focussed on most. For the Humanist inclined cultural tourist, culture(1) will be technically learnt through explicit instruction. Hence tourism requires a study of 'civilization', generally through learned guides (in book or in human form). A prime example was the classic Grand Tour of Europe, taken by English aristocrat gentlemen as a way of finishing their studies. The 
Tour would focus on those cities of the Old World which excelled in classical antiquity and the Renaissance, and the gentlemen of learning were usually accompanied by a 'Cicerone', a knowledgeable guide. Today, the Cicerone continues the same culture(1) role: "The role of the tourist guide is to guide visitors from abroad or the home country, in the language(s) of their choice, interpreting the natural and cultural heritage of the area of qualification". ${ }^{11}$ The guide book, itself, even the more 'alternative' guides (for travellers rather than for tourists), spawned in the wake of baby-boomers rite of passage to more off the beaten track destinations, are still today heavily focussed on culture(1). The Rough Guide to Egypt (Jacobs / Richardson, 2010), for example dedicates around 90\% of its 648 pages to culture(1) principally under the section headings "Guide" and "Contexts":

\begin{tabular}{|c|c|c|}
\hline Section title & Example sub-section(s) & Page numbers \\
\hline Colour section & Where to go & $1-24$ \\
\hline Basics & $\begin{array}{c}\text { Getting there; } \\
\text { Getting around }\end{array}$ & $25-68$ \\
\hline Guide & Cairo and the Pyramids & $69-596$ \\
\hline Contexts & History; Islam & $597-636$ \\
\hline Language & Vocabulary; Food and Drink & $637-648$ \\
\hline
\end{tabular}

Anthropologists, on the other hand, believe that culture(2) is learned through formal or unconscious parenting, socialization or other inculcation through long-term contact with others. It then becomes unconsciously shared amongst the group. It is in other words, "a system of inherited conceptions" (Geertz, 1973d: 89), "the form of things that people have in mind, their model of perceiving, relating, and otherwise interpreting them" (Goodenhough, 1957/1964:36), or simply, for the culture itself, whatever is 'normal' (Katan, 2004: 329). This is what Adele Quested was seeking in Forster's famous novel "A Passage to India", when she expressed a desire to see "the real India".

A culture's way of relating and interpreting things will be expressed in terms of a distinct way or style of doing (creating, eating, performing, speaking...), which being part of 'normality' will tend not to be perceived as notableby the Insiders (in comparison to local interest in 'civilization'), and hence will not necessarily be seen, heard or tasted by an Outsider - not to mention the fact that many aspects of this type of culture take time to experience.
So, what is visibly expressed and practiced is culture(2), while the core motivating values and beliefs that make a certain model of the world appear normal will be part of culture(3).

A fourth aspect of culture affects tourism in a very different, way, and questions the ethics of the first three. The very fact of being a tourist signifies (for some) a form of neo-colonialism: the colonial tourist exploiting the subaltern for his or her own pleasure. To an extent, the relatively new wave of tourism, 'eco', 'green' and in particular 'sustainable' tourism is the industry response to the criticism of exploitation. This level, for reasons of space, however, lies outside the scope of this paper.

\section{Culture as Heritage}

The objectives of the previously mentioned Master's are "to provide students with the necessary knowledge for them to take decisions related to the management of tourism, culture \& heritage activities in the Mediterranean area". Interestingly, it appears there is a difference between 'culture'(1) and 'heritage'. The English Heritage organisation itself focusses on heritage as tangible "property that descends to an heir" 12 . Heritage, here, is concerned with preserving property built in the past for future generations, and it is the interest in this which distinguishes 'heritage tourism' or 'cultural heritage tourism' from any other form of tourism. In his response to a 2004 discussion government paper on "Government and the Value of Culture", the chairman of English Heritage (2006: 20) said (emphasis added):

Time and again in our work all over England we see and hear people expressing their love for the distinctiveness of the places in which they live. Time and again it is to the historic environment that they point. The evidence speaks for itself, and did so most recently in "Heritage Counts", the annual audit of the state of the historic environment. And, paradoxically, as people's lives come to be less constrained by beliefs, traditions and customs and more subject to individual choice, the importance of the historic environment features increasingly in those choices.

Here, we can see the clear distinction within culture(1): 'heritage', based on 'place' or 'environment', and 'culture' understood as the Arts. The American National Trust, however, takes a wider view of heritage. For this organisation, 'cultural heritage tourism' means not only "travelling to experience the places, artefacts" (The English Heritage, heritage and culture), but also "to experience... the activities that authentically represent the 
stories and people of the past and present"13, i.e. culture(2). Tourism, ontologically, means travel, and logically must include some form of 'experience'. But the quality of a 'tourist experience', through the restraints of time, competence and often comfort, will necessarily be different to an insider's experience.

The UNESCO ${ }^{14}$ understanding of heritage is also clearly place oriented, though it divides heritage into 'cultural' and 'natural'. For UNESCO, 'cultural' means"of or pertaining to civilization", i.e. culture(1). In fact, UNESCO states that "the following shall be considered as 'cultural heritage': monuments... groups of buildings... and sites". "Monuments" includes anything from architecture, archaeology and art, from the primitive to the present. "Buildings" are a clear and closed category, while "sites" not only includes works of man but also "the combined works of nature and man". Natural heritage, on the other hand, concern sites of outstanding universal value from the aesthetic or scientific point of view untouched by the work of man:

- natural features: e.g. areas of scientific interest

- geological and physiographical formations: e.g. conservation habitat areas

- natural sites: e.g. areas of outstanding natural beauty So, for example, a small agricultural area in Northern Italy, known as Val d'Orcia is listed as part of 'cultural heritage' because, though it is rural, it is also inhabited and farmed. To be included as a World Heritage Site, the area must satisfy at least one of ten criteria. Val d'Orcia satisfies criterion iv and vi, as explained below:

Criterion (iv): "an outstanding example of a type of building, architectural or technological ensemble or landscape which illustrates (a) significant stage(s) in human history"15:

The Val d'Orcia is an exceptional reflection of the way the landscape was re-written in Renaissance times to reflect the ideals of good governance and to create aesthetically pleasing pictures... ${ }^{16}$

Criterion (vi): "directly or tangibly associated with events or living traditions, with ideas, or with beliefs, with artistic and literary works of outstanding universal significance"17:

The landscape of the Val d'Orcia was celebrated by painters from the Siennese School, which flourished during the Renaissance. Images of the Val d'Orcia, and particularly depictions of landscapes where people are depicted as living in harmony with nature, have come to be seen as icons of the Renaissance and have profoundly influenced the development of landscape thinking ${ }^{18}$.

Within the Euro-Mediterranean region, Italy has the most World Heritage Sites (47), followed by Spain (41). Clearly, distilling a country to a number of sites is a form of modelling. Tourists are encouraged to generali- se a country as a distorted amalgam of its 'sites'. More of a concern is the fact that this form of simplification of a country is extremely arbitrary. In fact, not all globally recognized unique sites are included in the world list of heritage sites. Israel's sites, for example, do not (yet) include the historic cities of Jerusalem or Bethlehem, nor is the Dead Sea included. Though the reason has more to do with present day territorial dispute rather than disagreement over intrinsic heritage value, these sites cannot (yet) be named or protected as World Heritage. Hence, the tourist is directed to the modern part of Tel Aviv rather than Jerusalem as one of the few world heritage sites (6) worthy of visit in Israel.

Apart from the arbitrary selection of sites to be included, individual national cultures tend to sacralise, to use MacCannell's (1999: 45) term, sites differently; or rather, what catches the (national) imagination is culture-bound. For example, though "The Sunday Times" portrayed the Val d'Orcia on the front cover of a supplement dedicated to Italy (01/03/2009), virtually no non-English student in Lecce, southern Italy, has so far been able to identify the picture with Italy ${ }^{19:}$

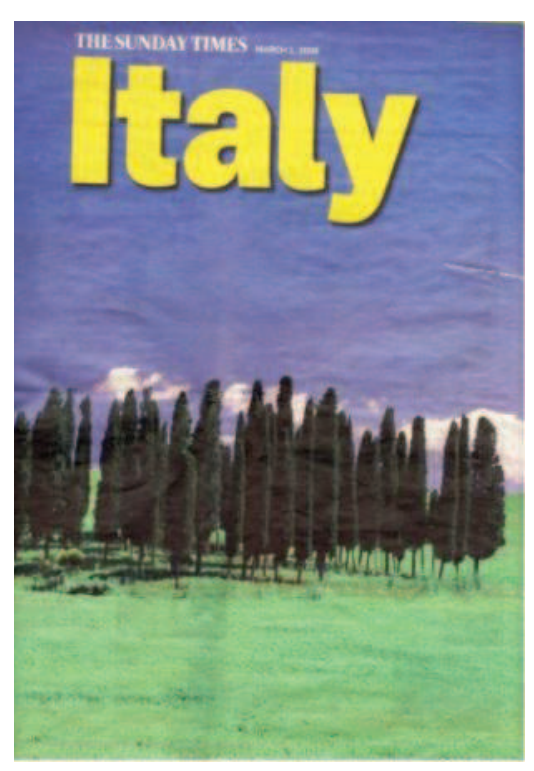

For most Italians asked, the clump of trees in the photograph is seen as just that: "a clump of trees". All cultural groups, as mentioned earlier, tend to delete part of reality, and focus on a small - and often different - part only. For example, a study (D'Egidio, 2009) focussing on Anglo / American, German and Italian newspaper articles (270,000 word corpus) regarding trips to Puglia, revealed striking differences in terms of what was deemed noteworthy, striking or simply "a tourist attraction". For the Anglo-Americans and Germans, for example, among the top 5 mentioned attractions were the "Trulli" in Puglia, one of the designated UNESCO World Heritage sites. For the English corpus, the Trulli were actually the first site 
on the frequency list with 147 mentions. In the German corpus, the Trulli came third with 83 mentions, preceded by 'the sea' and 'Lecce'. The Italian corpus mentioned the Trulli only 37 times, focussing instead on the qualities of the beach, sand, sea and the coastal towns. In all cases the focus deleted most of the actual reality, and disproportionately focussed on particular sights.

\section{Culture as Encounter}

There have been many typologies of tourist proposed in the literature, which have also been promptly criticised for their stereotyping (see Burns, 1999: 43-47). However, one aspect of the tourist compared to the traveller (see Kaplan, 1996) which does stand the test of time is that of the relative need or desire for the "environmental bubble". This concept, coined by Cohen (1972: 177) states, that a "mass tourist... likes to experience the novelty of the macro environment of a strange place from the security of a familiar microenvironment", or rather "environmental bubble". Tourists may be "institutional" on a package trip with pre-booked comforts with no responsibility, or extremely independent. But they will all be influenced by the physical and psychological "comfort factor" (Katan / Sergio-Straniero, 2003). A traveller, on the other hand, "will seek novelty at all costs: even discomfort and danger" (Cohen in Burns, 1999: 44).

This can be seen in the 'feel at home' leitmotif clearly visible in the previously cited Italian travel information regarding Malta. This 'comfort factor' clearly does not sit well, though, with any 'real', 'authentic' intercultural experience, which instead tends to result in 'culture shock'. This term was coined by Cora du Bois in 1951 and popularized by Oberg (1960), who defined it as the strain and anxiety resulting from losing all familiar signs in the context of a new culture. The cultural adjustment period is the length of time it takes a person to learn and acquire the behaviour, strategies and at least some of the value system necessary to adapt to living in another culture. This period is often represented as a " $\mathrm{J}$ " $U$ " or "W" curve or cline whereby the defensive reaction to culture shock is replaced over time with various levels of understanding, acceptance and indeed adaptation on the part of the visitor (e.g., Soriano Garcías, 2009; Katan, 2004: 329-338).

Clearly no tourist has the time (nor the inclination) to learn to adjust fully to another culture, which makes it difficult, for example, for the American Heritage or any other cultural tourist to travel and "experience the... activities" of another culture. The experience needs to be domesticated enough (i.e. within the environmental bubble to provide comfort) while left foreign enough to provide the need for novelty. Hence, the popularity of trips such as the following in Sharm El Sheik, which allow tourists to take an air-conditioned vehicle to "experience real Bedouin life" between 3 pm till after dinner - and always in the company of a tour leader: $:^{20}$
Escape from the noisy city to the serenity and atmosphere of the desert. Your tour starts with a two hour camel ride through the Desert, where you can experience the real Bedouin life and watch the sunset. After the amazing ride, you will stop at the highest point in the valley where you will see the heavens as it is supposed to be seen, covered with a blanket of the stars. Then you can taste the Bedouin tea with herbs (Habak) and have a real Bedouin dinner under the candles light in the middle of the desert. After dinner, you will be taken back to your hotel.

\section{Includes}

- Pick up and drop off at your hotel

- All transfers by an air-conditioned vehicle

- Tour leader assistance during the tour

- Bedouin tea, dinner and mineral water during dinner

- All taxes \& service charges

Having personally experienced this particular "real Bedouin life "I can also vouchsafe for the level of instruction and cleanliness of the Bedouins we were introduced to. To a certain extent all tourist activity is "packaged" in the same way, whether it be a zoo, a museum, or a traditional show at the theatre. In all cases, the foreign is framed and domesticated to be consumed relatively passively within a scheduled time. Also, the decision to participate will be motivated by tourist culture(3) rather than any Insider beliefs and values. The possibility of behaving or acting as an Insider or appreciating any of the Insider values will necessarily be limited. Hence, the 'real' becomes what Boorstin (in Larson / Urry, 2011: 20) rather derogatorily terms a "pseudo-event", or from the point of view of the tourist herself a "pseudo experience" (Nash, 1981: 465; Osborne, 2000: 73), in short, "staged authenticity" (MacCannell, 1973).

Yet this form of staged authenticity is now not the only way for organised tourists to gain 'real experience'. In Israel, for example, there are two types of short-stay tourism inspired by the conflict: 'adventure', and 'responsible' tourism. They both differ from the pseudo-experience in that they will be following exactly what certain presentday Insiders will be doing. Clearly, though the dress and even the way the tourists behave may well be indistinguishable from the locals, the underlying motivating values and beliefs will still be radically different. The first case is an example of fully active participation: ${ }^{21}$

\section{Hebron sells itself on terror tourism \\ March 82003 \\ Adventure tourism will pale into insignificance next to the thrills planned at the Jewish settlement of Gush Etzion. Ed O'Loughlin reports from Je- rusalem.}

Starting this year, the Gush Etzion Tourism Association will fly in small groups of tourists for what is being variously billed as an adventure holiday or an anti-terrorism course.

American immigrant Jay Greenwald, who came up with the idea, says that the holidaymakers will pay 
\$US5500 a head ... for a five-day intensive introduction to "the world of terrorism".

Dressed in military fatigues, the tourists will undergo various forms of training at the hands of Israeli Defence Force experts, including a live-fire simulation of an attack on a settlement.

There will be wild things, sure, like going up in helicopters and firing an M16 and an Uzi, but there will also be other stuff, like helping to move injured people out of a building, taking command of the situation, that sort of thing," Mr Greenwald said. ...

He added: "There'll also be jeeping, and a barbecue in the desert."

The focus is on adrenaline and hands-on physical, and hence to a large extent this type of holiday is no different to any other adventure holiday. Participation with the host culture, in line with $90 \%$ of mass tourism holidays (see Dann, 1996: 68) is not part of the package. In fact, the article continues with the following:

Asked if the holidaymakers would see Palestinians, Mr Greenwald said: "I would assume that they would, just as we do as they drive down the road. They don't live in cages, you know." Local Arabs are not happy about becoming specimens in the settler's zoo. Dr SaebErekat, a minister in the Palestinian Authority, denounced the new tourist initiative as a form of terrorism itself.

The environmental bubble is still as complete as any classic 'sun sea and sand' holiday. One of the most important Insiders, in this case Palestinians, provide an incidental backdrop to the holiday. Emerging more recently is the "political' or 'responsible "holiday, as recounted, for example, on the "Green Olivealternative tours" website. The emphasis of these tours is the encounter itself. The tourists meet, eat and stay with the locals, to hear their stories. Importantly the tourists literally follow the footsteps of 'the Other', experiencing for a moment a part of the Others' everyday life ${ }^{22}$ :

\section{Political Tourism in the West Bank}

\section{Benjamin Barthe • Le Monde 11 July 2008}

A labyrinth of metallic turnstiles, electronic detectors and barbed wire fencing under a roof of sheet metal whitened by the sun of Palestine: it is checkpoint of Huwara, gateway to Nablus, the capital of the northern West Bank, and it is there that Thomas and Charlotte, two Parisian thirty year-olds, chose to spend part of their honeymoon. Arriving in Israel initially to visit a friend in Tel Aviv, the young bridegrooms quickly felt the need to see " the opposite side " of Israeli-Palestinian conflict. After a few days in Jerusalem, including a visit of Yad Vashem, the painful memorial of the Holocaust, they reserved two places on an 'alternative tour' by an agency which refuses to reduce Palestine to a photo opportunity in front of the Church of the Nativity in Bethlehem, or on the Dome of the Rock in Jerusalem.
Often Guide books, written by fellow nationals give tips regarding Insider practices, second guessing the touristmodel of reality, when encountering the Other, and forewarn of likely faux pas:

If you are visiting an Albanian home you will be offered a pair of slippers or plastic sandals to wear while you are indoors ... their questions often become very personal very quickly, although usually they do not mean to be intrusive. It is especially difficult to know how to answer questions about your salary from (for example) a pensioner whose income is probably less than US\$100 a month. (The Bradt Guide Albania, Gloyer, 2008: 46).

This type of comment demonstrates the importance of a 'local informer' who understands the Outsider's model of reality; something that, as we shall see, the translator is unwilling to do.

Yet, most guides are unable to fathom Insider culture(3) especially when what is seen is judged negatively. For example, the Bradt Guide describes the following practice from the point of view of the model British reader. "Doing business in Albania is fraught with difficulty due to the prevalence of corruption, the presence of organised crime, and the weakness of the judicial system". Though this is certainly useful information, the Outsider reader has a simplified, generalised and distorted view of doing business in Albania. There is no information about Insider meaning about what the author terms "corruption", and gives the impression that the whole country is involved.What would be more useful is an Insider's view, and definition of, the generalised (?) practice of paying an illegal extra sum for a service.

Below is an example of how The Rough Guide began to fathom the Insider world related to a visible practice. In the first edition of the guide (Belford et al., 1990: 14) regarding "Getting Around" in Italy, we have an interpretation of a visible culture(2) behaviour. Unable to understand the culturally shared significance of the behaviour, the Guide gave misleading advice to its readers: "However you get around on the roads, bear in mind that the traffic can be appalling. The secret is to make it very clear what you're going to do, using your horn as much as possible, and then do it with great determination".

By 2003 (p. 32), the guide had changed its tune. The traffic was no longer appalling, but "heavy". More importantly, the authors ${ }^{23}$ had begun to understand some of the Insiders' (culture(3)) values and beliefs regarding the behaviour itself: "The secret is to make it very clear what you're going to do - and then do it...Contrary to popular belief, Italians don't go round sounding their horns all the time - in fact it's taken as a sign of letting things get to you if you resort to such crude tactics. There are exceptions to this rule, though - notably in Naples".

\section{Translating encounters}

A number of written travel guides take account of 
probable "encounters" by supplying key language help. We have already noted that the Rough Guide devotes space (9 pages out of 648 in the guide to Egypt) to language. These language guides famously began with the Berlitz guides and phrase books in the 1880's. Tourist phrase books have been parodied ever since, due to the difficulties in using them and the, at times, odd expressions offered to the tourist. A BBC article ${ }^{24}$ on the subject notes that though translations of the "My postillion has been struck by lightning" type are no longer to be found, there are still examples of the seemingly unnecessary, such as translation equivalents for "Does anyone here speak English?" (also to be found in the Rough Guide books).

Barthes ([1970] 1983: 13) is even more critical of language guides: "Open a travel guide book: usually you will find a brief lexicon which strangely enough concerns only boring and useless things: customs, mail, the hotel, the barber, the doctor, prices". His reasoning is that the encounter, to be truly appreciated as such must be performed as a true Outsider. Hence: "The only lexicon that counts is the one which refers to the rendezvous", which Barthes understands as full immersion with no foreign language competence: "The dream: to know a foreign (alien) language and yet not to understand it: to perceive the difference in it without that difference ever being recuperated by the superficial sociality of discourse..." (ibid.: 6).

This type of encounter is clearly outside the realms of "travel and tourism", and will remain a dream - if not a nightmare when the realisation comes that 'perceiving difference' will not help when attempting to eat,travel or visit, outside the realms of the environmental bubble. Tourists, clearly, need help to overcome the language barrier in these practical encounters, which is where translation comes in. However, tourism translation is one aspect of tourism and culture which is rarely considered as important. One only needs to Google the tourist 'howler' and 'gaffe' translations to realise the enormity of language incompetence in tourism translation. Not only should language competence be a prerequisite to effective translation, but there should also be the need for cultural competence (Katan 2004). At the most superficial and visible level there is the problem of 'culturemes' (Vermeer, 2004), regarding the many geographical, legal, institutional, and indeed gastronomic terms that have no equivalence in a second language. For this reason, in fact, terms are often better simply loaned, such as 'fjord', 'force majeure', 'Reichstag 'and 'spaghetti'.

However, often the loan words and their literal translations do not refer to the same thing nor to exactly the same organization of things. For example, we are all aware that a

\begin{tabular}{|c|c|c|c|c|c|}
\hline Type & Function & $\begin{array}{c}\text { Desired } \\
\text { reader } \\
\text { response / } \\
\text { effect }\end{array}$ & $\begin{array}{c}\text { Type of } \\
\text { language }\end{array}$ & Focus & $\begin{array}{c}\text { Example } \\
\text { publications }\end{array}$ \\
\hline $\begin{array}{c}\text { Vouloir } \\
\text { faire }\end{array}$ & $\begin{array}{c}\text { Stimulate } \\
\text { interest } \\
\text { "I want to } \\
\text { go there" }\end{array}$ & $\begin{array}{c}\text { Colourful, } \\
\text { emotive, } \\
\text { superlatives }\end{array}$ & $\begin{array}{c}\text { The } \\
\text { destination, } \\
\text { generalities; } \\
\text { values, push } \\
\text { factors }\end{array}$ & $\begin{array}{c}\text { Posters, } \\
\text { coffee-table } \\
\text { books }\end{array}$ \\
\hline $\begin{array}{c}\text { Savoir } \\
\text { faire }\end{array}$ & $\begin{array}{c}\text { Give } \\
\text { knowledge }\end{array}$ & $\begin{array}{c}\text { know more } \\
\text { about ..." }\end{array}$ & $\begin{array}{c}\text { Lexically } \\
\text { dense, } \\
\text { factual, } \\
\text { chronological }\end{array}$ & $\begin{array}{c}\text { History, art, } \\
\text { architecture, } \\
\text { 'culture', } \\
\text { background }\end{array}$ & $\begin{array}{c}\text { in-depth } \\
\text { guide books, } \\
\text { Michelin } \\
\text { Green guides }\end{array}$ \\
\hline $\begin{array}{c}\text { Pouvoir } \\
\text { plus } \\
\text { faire }\end{array}$ & Empower & $\begin{array}{c}\text { "I can do } \\
\text { (visit, eat, } \\
\text { stay ...)" }\end{array}$ & $\begin{array}{c}\text { Readable, } \\
\text { clear } \\
\text { instructional } \\
\text { language }\end{array}$ & $\begin{array}{c}\text { Practical, } \\
\text { 'how-to' for } \\
\text { the DIY } \\
\text { tourist }\end{array}$ & $\begin{array}{c}\text { Lonely Planet, } \\
\text { Rough Guide }\end{array}$ \\
\hline
\end{tabular}

tourist breakfast may be 'English' or 'Continental', but many are not aware that such international terms as 'tea', 'coffee' and 'toast' also need to be framed with national provenance or through a 'thick translation'(Appiah (1993/2004; Katan, forthcoming), with an explanation of local difference. Italian 'coffee' and 'toast', for example, is significantly different to their English equivalents; and often a 'cappuccino', though prepared with the same ingredients will look and taste significantly different in the two countries, due not only to differing competences but importantly to differing tastes. The literal, or close equivalent, translation of Puglia's flagship culinary dish 'orecchiette con cime di rapa' creates unappetising connotations, and unfortunately is often found in translated menus due to a lack of lingua-cultural competence. The main problem is not with the 'little eared pasta' which can be turned into 'little ear-shaped pasta', but with the 'cime di rapa', which translates literally into 'the tops of rapini', 'broccoli rabe' 'raap' or 'raab'. All these correct synonyms for 'rapa/rapini' are too technical for the tourist reader, and would leave her with a translation almost as foreignised (Venuti, 1995) as the original. A more domesticated (ibid) translation, would be 'turnip tops' (a subspecies of the Italian vegetable), but turnip tops in Britain are generally thought of as unfit for human consumption, and are fed to animals.This hidden meaning or culturebound interpretation of everyday language (see Katan / Trickey, 1998), such as: "guest", "host", "friend", "private" and "sacred"will often result in language shock (Agar, 1994: 60), or culture shock itself.

Hence the (underrated) importance of competent translators to mediate the myriad of unsuspected 'culturebound' terms (see Katan, 2009: 79-80). How to translate and how much, for example, to domesticate or foreignise, will depend on the skopos, or purpose of the text. Greimas (in Stivale, 1987) has usefully considered language in terms of: vouloir (desire), savoir (knowledge), pouvoir (ability) and faire (doing), which is also extremely useful, for example, for translators of guide books. A translator must decide which aspect is the most prominent: 
An example to illustrate the type of problem encountered in translating across cultures is given below. It is an extract from a brochure published in Trieste, explaining how to order particular types of coffee in a coffee-bar. The original guide was provided as a pouvoir faire guide for Italian Outsiders in Trieste, subsequently published in English as below:

\section{To each his own coffee \\ In a Triestine caffè, one can hear orders like this: "Give me a long decaffeinated cappuccino in a cold glass withoutlittle foam.”... The cappuccino is not the same as it is everywhere else.... \\ "Nero" and its variations \\ Yes, coffee is still coffee, but if you wish to enter into the local spirit, then it is best to ask for a 'nero'. Which means exactly what one would expect: a black coffee with nothing added and no variations.}

The translation is fairly literal, which provides the reader with a number of problems, especially if the purpose is pouvoir faire. How is a non-Italian to use this information? First, it would appear that "in a Triestine cafe" English is spoken. Second, we discover that ordering a cappuccino is "not the same" in Trieste; and thirdly we can ask for a 'nero', if we wish to "enter into the local spirit". The problem with the first point is that this information is clearly not pouvoir faire, as English is generally not spoken in Triestine caffès. Of course, if the text is taken at its face value, then it would appear that the Triestini are rude (no 'please') and/or speak bad English. In the second case, the tourist is left wondering about how'cappuccino' is different in Trieste - for there is no further information. Admittedly there was no further information in Italian either. However, Italians, forewarned, have the linguistic competence to ask the barista what the difference is. What would have been more useful for a pouvoir faire type of guide would have been to warn the reader that the Triestine cappuccino is extremely small - even smaller than a normal Italian cappuccino - and is more like a 'macchiato'.

Third, there is no help with the pronunciation of 'nero', so instead of asking for a black coffee, a tourist is likely to be heard asking for the actor Robert de Niro, for in Italian 'nero' rhymes with 'pharaoh'. Without this added explicitation, or "thick translation", the visitor will be unable to use the guide as intended. A counter example, below, is a showcase label in the dinosaur room at the Natural History Museum, London:

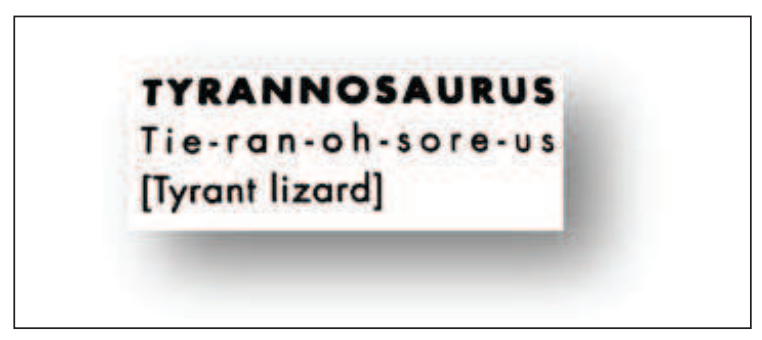

\section{Translating style}

Culture(2) has to do with inculcated way of doing things, appropriacy, which includes expected language style. If the translator is able to produce a text which mirrors the reader's expected textual conventions, then uptake of the vouloir, savoir or pouvoir faire intention is more likely to be guaranteed.

An official translation (see Katan, 2004: 282-3) into English of a pouvoir faire text for passengers regarding Italian rail tickets shows how translators tend to be sourceculture(2) oriented. The text in English conforms to the accepted style of Italian official writing. There is a focus on completeness, and on precision, much like a legal text - even though this text will be read by a much more heterogeneous group of readers, most of whom will not necessarily have English as their first language. An example of (unnecessary for some) completeness is for example (italics added) "Tickets are only valid if they are stamped by means of the appropriate ticket-stamping machines or if passengers, of their own initiative, pay a charge". This culture-bound approach is termed KILC style (Keep it long and complete/complex) as a natural polar orientation to the well-documented KISS style (ibid.: 261-262; 2006). The words 'appropriate' and 'of their initiative' add to the length and completeness of the sentence, but do not add any relevant further information that could be usefully used by the reader.

KISSy style focusses on the conversational, readerfriendly style of speaking or writing. KILCy, on the other hand, favours formality and a more erudite language. Both styles engender trust in the authority of the speaker or writer for different culture-bound reasons. KILCy style gives the reader rich detail, which points to a knowledgeable party imparting information. Anglo and northern European readers, though, will have been inculcated into expecting a reader-friendly text, which they can skim through (FAQs, personal pronouns, bullet points and so on (see Katan, 2004)).

Expected 'normal' styles polarise across cultures even more when tourists are being given specialised, archaeological, architectural or artistic information. Specialized lexis will either be emphasizedto show authority and mastery of the subject (KILC) or will be avoided to be clear and digestible to the lay reader (KISS). In general, awareness of these culture-bound differences is extremely low, due partly to the translators' lack of qualifications and status, but also to the profession's own traditionaltext fidelity norms (Katan, 2011). The result is frustrated tourists, unsold guide books and reduced foreign tourist access to the host country and reduced ability to pouvoir faire.

A second area regarding text provision is the implicit culture-bound information that would transform texts for Insiders into texts that can become fully pouvoir faire texts for Outsiders. If we return to the Italian rail text, we have already mentionedthe "appropriate ticket-stamping machines". These machines are an unknown quantity for most Outsiders. A glance at blog pages giving travel ad- 
vice and tips shows how information can more usefully be given. The example below ${ }^{25}$ talking about the French system, explains the procedure from the point of the user and not the institution:

Paris Train / Metro Ticket Validation / Punching June 16, 2008 in Tickets | 3 comments

Validating or punching your train ticket or "billet" [bee-yay] is required when traveling on the Transilien, Ter, and various other Paris regional trains (not Metro) going to other cities in the Ile-de-France region that contains Paris.

The machines to validate or "composter" [com-postay] the little purple or white Billet Ile-de-France tickets look like this:

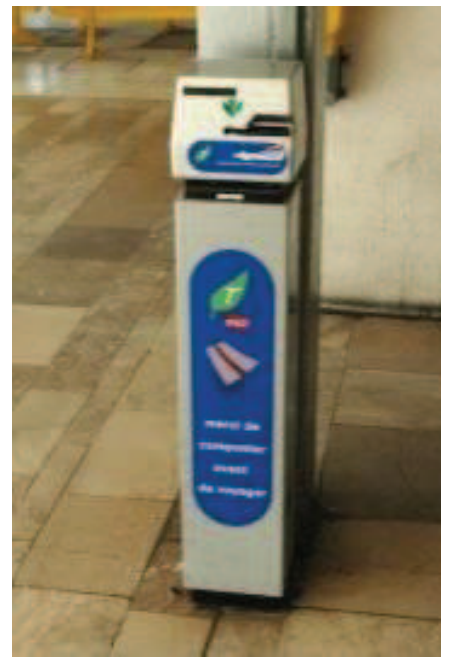

To use the machine, lay your ticket with the front side face down, magnetic stripe facing up, on the black plastic area and slide the ticket to the left. Wait for the machine to make a loud stamping noise after which your ticket should be punched and validated. Orientation of the ticket, besides magnetic strip facing up, doesn't matter.

Don't confuse these machines with the TGV Ticket Validation Machines, which are yellow and take the larger format tickets.

If you've used your Ile-de-France Ticket/Billet for travel on a Metro line before boarding a Transilien/Ter train, you don't have to validate the ticket as it's done automatically by the Metro/RER turnstiles.

Of particular interest is the way the writer has taken the position of the Outsider reader and imagined what s/ he would need to know. There is pronunciation help and there is relevant further information that could be usefully used by the Outsider who otherwise would have no access to the context. In particular, th visual and written description of what an "appropriate stamping machine" actually looks like, with also a comparison of what an "inappropriate' machine looks like.

\section{Culture as a system of values}

People are inculcated into a particular way of perceiving, interpreting and valuing the world. In fact, to be a member of a particular culture means to share the values inherent in a weltanschauung, "mental programming" (Hofstede, 2001), or model, map or view of the perceivable world. The American anthropologists Kroeber and Kluckhohn (1952:181) made an exhaustive attempt to classify 164 definitions of culture. Their own conclusion was in two parts. First: "the essential core of culture consists of traditional (i.e., historically derived and selected) ideas and especially their attached values". These orient individual and community ways of doing things. They are preferences for certain outcomes over others, or as Hofstede aptly put it (1991: 8): "values are feelings with an arrow on it: they have a plus and a minus side", and they guide what is felt to be correct, good or normal. The hierarchy of preferred value orientations are seen as the result of a community response to universal human needs or problems, such as how to pass on knowledge, relations to time, and those between the individual and the group.

At this level of culture we can talk about the "tourist gaze". As Urry and Larson explain (2011), the gaze is constructed through signs which a culture perceives and interprets according to its own value system. We have already noted how Italians, Germans and Anglo-Americans perceive Puglia differently. The values behind this perception have also much to do with two different tourist cultures: mass tourism (values: 'sun, sea and sand', relaxation, ludic possibilities) and post-tourism (values: 'off the beaten track', 'genuine', 'authentic', nostalgia). The result is that the Anglo gaze is more towards the rural hinterland, while the Italian gaze is more coastal.

A similar survey (Orlandi, 2009a), this time focussing on tourist blog pages about London noted other patterned culture-bound differences. From the point of view ofheritage sites, similarities were much as expected.The differences included the accentuated Italian gaze, or mustsees: Harrods, the red buses and taxis. This relates to the second part of the Kluckhohn definition: "culture systems may, on the one hand, be considered as products of action, on the other, as conditioning elements of future action". These "must sees" are part of the conditioning elements and will have already been seen virtually, heard or read about, as in the following example taken from Orlandi's (2009b) blog corpus (italics added):

The last day was spent doing the normal touristy things: Big Ben, Parliament, Westminster, London Tower MINKYRUNNER.

The major sights - Big Ben, Westminster Abbey, Buckingham Palace-BRAN120

...the classics - [...] Big Ben, Westminster and Buckingham Palace -AUTHOR UNKNOWN. 
And from the Italian corpus:

Getting out of Westminster station and finding ourselves in front of Big Ben lit up just like in the best post cards or pictures in who-knows-what guide- VICKY E MANU $^{26}$

\section{Be / Do orientation}

Regarding preferences, it appeared that the Italian bloggersvisited (or at least wrote about) more sites than their English counterparts, possibly to satisfy a belief thatthe full extent of the enshrined sites should be visited in 'the pilgrimage'. The Anglo-American corpus, while lower on references to sites, included more activities, e.g. watching musicians, strolling through the park, wandering around the gallery - all peripheral to the sacralisation proper. What prevails, through the language, are two different tourist culture(3) systems: one focusses on observing "what there is" $(\mathrm{Be})$ while the other focusses more on "what to do" (Do). This 'Be' or 'Do' pattern has been classified in terms of an orientation Activity (Kluckhohn/Strodtbeck, 1961), and as is one of many culturalorientations which lie at the base of many culture-bound appropriate or natural ways of perceiving the world (see Katan, 2004).

The one 'doing' activity that was extremely frequently discussed in the Italian corpus only was the expressed desire to purchase a Harrods plastic bag, a sure sign of conquest or pilgrimage. Again from Orlandi's Italian blog corpus (2009b, my translation): ${ }^{27}$

[...] the famous green bag with the Harrods signature (which I obviously bought for the reasonable sum of £16.00” -BEATRICE ALLEGRA

[we bought] the really famous shop bag, so totally loved in Italy!"- ALE83

In terms of MacCannell's (1999: 45) sight sacralisation, the Harrods bag is an example of the "mechanical reproduction of the sacred object [and is the] most responsible for setting the tourist in motion on his journey to find the true object." Hence, for successful promotion it is essential to translate, or rather adapt, the text to include the sacred objects according to target-culture realities.

\section{High / Low context}

If we return to culture(2) KISS/KILC writing styles, we can find an underlying link to a cluster of culture(3) values in E.T. Hall's "Contexting Theory" (in Katan, 2004: 245-279). The transparent and tourist friendly style is part of a value focussing on the text, 'low context communication' (LCC), where all the information that the reader needs at that moment is clearly transmitted. The alternate orientation, focussing on the context, presumes that the text is not the principal source for pouvoir faire. A tourist may act independently of a text, and may well instead put more trust on personal help. Hence, in looking for a restaurant, while one culture will naturally feel it is right to consult a text another will equally be happier asking a local person what they recommend. In this second case, the preference is for 'high context communication' (HCC) where the communication is strongly personalised and influenced by the particular context. HCC also in general will be more sensitive to people and their feelings, whereas LCC is more pragmatic and task oriented.

This HCC form of communication also presumes that much information is already available or implicit from the context, and this will greatly affect whether or not tourist information is written, and if so, how. The following 'normal' explicit, task-oriented LCC advert for a hotel in Scotland would, for example create a culture shock and put off the majority of HCC Italians: "We look forward to welcoming you to Ardachy House and hope that you will enjoy a tranquil interlude away from the roar of traffic and stress of city life. Well behaved children and/or dogs welcome!"28

The bald and insensitive statement in the text relegating children to the same level as dogs also grates against the particularist and inclusive values of 'the family' (see also Manca /TogniniBonelli, 2002). The hotel owner, however, in tune with strongly felt (and generally shared) individualist and less family oriented values of an Anglo culture(3) has produced a locally successful vouloir text designed for those who value tranquillity. Clearly, the conflict that is engendered through the implicit message "Children should be seen and not heard" and may be classified with dogs is not easily resolvable with an explanatory travel tip or through a thick translation.

\section{Conclusion}

As has been shown, there are three principal ways in which culture impinges on tourism - apart from the cultural studies perspective. Culture, for tourists, is heritage, both natural and man-made. This is the culture(1) that tourist guides usually focus on. Culture(2) is the practices and traditions of a people, and is visible in people's dayto-to-day behaviour. These will be seen as more or less staged authentic encounters. Culture(3) is hidden to the Outsider, as it is the system of internal values and beliefs that both form the model of reality and guide it. Tourists, travelling abroad with their culture(3) local maps or model of reality will interpret what they see according to their own tourist gaze, thus distorting, generalising or simply deleting much of what is abroad.

It is, then, the job of those about to embark on a career in the travel business to be first and foremost competent interculturalists with regard to the country-cultures they will be working with. Second, they will need to become translation mediators or interpreters, ready to gauge the differences between Insider and tourist gaze direction, and ready to balance the need for an environmental bubble with encounters at all levels of culture. 


\section{References}

Agar, Michael

1994 Language Shock: Understanding the Culture of Conversation. New York: William Morrow and Company.

Appiah, Kwame Antony

2000 "Thick Translation." In Venuti, Lawrence (ed) The Translation Studies Reader. London/New York: Routledge. 417-429.

Bandler, Richard / Grinder, John

1975 The Structure of Magic I. Palo Alto (CA): Science and Behavior Books.

Barthes, Ronald

[1970] 1983 Empire of Signs. Trans. by R. Howard. New York: Hill and Wang.

Belford, Ros / Dunford, Martin / Woolfrey, Celia

2003. The Rough Guide to Italy. London: Rough Guide Books.

Belford, Ros / Dunford, Martin / Ellingham, M.

1990. The Rough Guide to Italy. London: Rough Guide Books.

Bonelli Tognini, Elena / Manca, Elena

2002. "Welcoming children, pets and guests: towards functional equivalence in the languages of 'Agriturismo' and 'Farmhouse Holidays"'. In K.Aijmer / Battenberg (Eds), Language and Computers:Advances in Corpus Linguistics (ICAME 23).), pp. 371-385. Amsterdam/ New York: Rodopi.

Burns, Peter

1999 An Introduction to Tourism and Anthropology. London: Routledge.

Calleya, Stephen

2005 Evaluating Euro-Mediterranean Relations. Oxford: Routledge.

Cohen, Erik

1972 "Towards a Sociology of International Tourism". Social Research 39 (1): 164-182.

Congress of Local and Regional Authorities.

2006 Heritage for the future - Realising the economic and social potential of a key asset. Council of Europe (Local and Regional Action No.6).

Dann, Graham

1996 The Language of Tourism. A Sociological Perspective. Oxford: CAB International

D'Egidio, Angela

2009 Eyeing Puglia. Comparing the tourist gaze in English, Italian and German travel articles. In Rivista Internazionale di Tecnica della Traduzione, 11: 201-212.

Geertz, Clifford

1973 The Interpretation of Cultures. New York: Basic Books.

Gloyer, Gillian

2008 Albania. London: Bradt Travel Guides.

Goodenough, Ward

1957/1964 "Cultural Anthropology and Linguistics". In

D. Hymes (Ed.) Language in Culture and Society: a Reader in Linguistics and Anthropology (pp. 36-9) New York: Harper \& Row.
Hofstede, Geert

2001 Culture's Consequences, Comparing Values, Behaviors, Institutions, and Organizations Across Nations, Newbury Park, CA: Sage Publications.

Hofstede, Geert

1991 Cultures and Organizations: Software of the Mind. London: McGraw-Hill.

Jenks, Chris

1993 Culture. London/New York: Routledge.

Jacobs, Daniel / Richardson, Dan

2010 The Rough Guide to Egypt. London: Rough Guides Limited.

Kaplan, Caren

1996 Questions of Travel: The Discourse of Displacement. London: Duke University Press.

Katan, David

Forthcoming "Cultural Approaches to Translation". In The Encyclopedia of Applied linguistics (Ed.). Chapelle, C. A., Oxford: Wiley-Blackwell

Katan, David

2009 "Translation as Intercultural Communication" (pp. 74-92). In J. Munday (Ed.), The Routledge Companion to Translation Studies. London/New York: Routledge.

Katan, David

2004 Translating Cultures (2 $2^{\text {nd }}$ edition): An Introduction for Translators, Interpreters and Mediators, St. Jerome Publishing, Manchester

Katan, David / Sergio-Straniero, Francesco

2003 "Submerged Ideologies in Media Translating".In P. M. Calzada (Ed.) Apropos of Ideology: Translation Studies on Ideology - Ideologies in Translation Studies, St. Jerome, Manchester UK/Northampton MA, pp. 130-144.

Katan, David / Trickey, David

1998 "Negotiating Meaning across Cultures: using the Meta Model in NLP as an International Business Communication Tool”. In D. Evans (Ed.) Communicative Ability and Cultural Awareness: A Key to International Corporate Success (pp. 114-119). VIII ENCoDe International Conference. Groupe EDHEC: Nice.

Kluckhohn, Florence / Strodtbeck, Fred

1961 Variations in Value Orientations, Evanston, IL: Row, Peterson \& Co.

Korzybski, Alfred

1958 Science and Sanity, Lakeville, CT: The International Non-Aristotelian Library Publishing Company, 4th Edition.

Kroeber, Alfred / Kluckhohn, Clyde

1952 Cultures: A Critical Review of Concepts and Definitions, Peabody Museum Papers Vol. 47:1, Cambridge, Mass.: Harvard University

MacCannell, Dean

1999 The tourist: a new theory of the leisure class. Berkely: University of California Press.

MacCannell, Dean

1973 "Staged authenticity: arrangements of social space in tourist settings". American Sociological Review 79: 589-603. 
Oberg, Kalvero

1960 "Cultural Shock: Adjustment to New Cultural Environments". Practical Anthropology, 7: 177-82.

Office for National Statistics.

2011 Sustainable Tourism: A Review of Indicators. UK. http://www.ons.gov.uk/ons/dcp171776_236479.pdf. Accessed 24/11/2011

Orlandi, Cinzia

2009a "Blogging about London. Comparing the Italian and Anglo-American Tourist Gaze". Rivista Internazionale di Tecnica della Traduzione, 11: 189-200.

Orlandi, Cinzia

2009b Blogging about London. Comparing the Italian and Anglo-American Tourist Gaze. In Rivista Internazionale di Tecnica della Traduzione. Postgraduate thesis deposited at University of the Salento (Lecce).

Osborne, Peter

2000 Travelling Light: photography, travel and visual culture. Manchester University Press: Manchester.

Nash, Dennison

1981 "Tourism as an Anthropological Subject", Current Anthropology, 22(5): 461-85.

Richards, Greg

1996 Cultural Tourism in Europe. Wallingford: CABI. Online at www.tram-research.com/atlas. Accessed $27 / 11 / 2011$.

Ryan, Chris

1991 Recreational Tourism: A Social Science Perspective, London: Routledge.

Schleifer, Ronald

1987 A. J.Greimas and the Nature of Meaning: Linguistics, Semiotics and Discourse Theory. London: Croom Helm.

Soriano García, Inmaculada

2009 "Direction of mobility and its implications for the Ucurve theory". Cultus, 2: 79-96.

Spencer-Oatey, Helen / Franklin, P.

2009 Intercultural Interaction: A Multidisciplinary Approach to Intercultural Communication. Basingstoke, Hampshire: Palgrave-Macmillan

Urry, John / Larsen, Jonas

2011 [2002]. TheTourist Gaze (3rd Ed.). London: Sage publications.

Venuti, Lawrence

1995 The Translator's Invisibility: A History of Translation. London/New York: Routledge.

\section{Notes}

1 www.uniba.it/.../master..../master0809/master08.emtc.profile.

2 www.etc-corporate.org/resources/.../ETC

CityTourism\&Culture_LR. Accessed 22/11/2011

3 epress.anu.edu.au/culture_sustainable/ch14.pdf. Accessed $22 / 11 / 2011$

4 www.uniba.it/.../master..../master0809/master08.emtc.profile. pdf. Accessed 22/11/2011

5 unesdoc.unesco.org/images/0012/001226/122619eo.pdf. Accessed 22/11/2011

6 www.oecd.org/dataoecd/35/1/42040178.pdf. Accessed $22 / 11 / 2011$

7 www.gov.im/tourism/landing.aspx?category=culture. Accessed $22 / 11 / 2011$

8 www.unesco.org/en/unitwin/access-by.../culture/culturaltourism. Accessed 22/11/2011

9 http://www.visitireland.com. Interestingly, the equivalent site for Britain has recently changed, and has encompassed the concept of cosmopolitan and multicultural, and the commentators who now invite you to Britain now include Chinese, Indian and Pakistani Britons (see http://www.visitbritain.com/ en/EN).

10 Sono sempre numerosi i turisti che scelgono Malta per le vacanze balneari, dove è possibile abbinare lo studio della lingue inglese praticamente tutto l'anno. L'isola è una destinazione adatta agli italiani che si sentono come a casa, perché i maltesi parlano - oltre all'inglese e al maltese - anche, e molto bene, la nostra lingua, fanno il tifo per le nostre squadre seguendo il nostro campionato di calcio, guardano le nostre trasmissioni televisive.

11 From the British Association of Tour Guides' site. http://www. unitetheunion.org/sectors/community youth workers/unite and_your_organisation/association_of_professional_to/definition_of_a_tourist_guide.aspx. Accessed 25/11/2011

12 Miriam Webster Dictionary: www.merriam-webster.com. Accessed 22/11/2011

$13 \mathrm{http}: / /$ www.preservationnation.org/issues/heritage-tourism. Accessed 22/11/2011

$14 \mathrm{http}: / /$ whc.unesco.org/en/conventiontext. Accessed 22/11/2011

15 http://whc.unesco.org/en/criteria. Accessed 22/11/2011

16 www.sitiunesco.it/en/la-val-dorcia.htm. Accessed 22/11/2011

17 http://whc.unesco.org/en/criteria. Accessed 22/11/2011

18 www.sitiunesco.it/en/la-val-dorcia.htm. Accessed 22/11/2011

19 The result of an informal survey (2009-2011) of 200-300 students, some on the MA course coming from a variety of Eastern and Southern European countries, while most come from Lecce itself. All the students were shown the photograph without the title and were asked which country it might represent. Most suggested Austria or even Britain. 
$20 \mathrm{http}: / /$ www.city-discovery.com/sharm-el-sheikh/tour. php?id=2791. Accessed 22/11/2011

$21 \mathrm{http}: / / \mathrm{www} \cdot$ theage.com.au/articles/2003/03/07/1046826527588.html. Accessed 22/11/2011

22 http://www.toursinenglish.com/2007/01/political-tourism-inwest-bank.html. Accessed 22/11/2011

23 Each guide was written by a team of 3 authors, and there was only one change for the 2003 edition.

24 http://news.bbc.co.uk/dna/place-lancashire/plain/A25136426. Accessed 22/11/2011

$25 \mathrm{http} / /$ parisbytrain.com/paris-trainmetro-ticket-validationpunching. Accessed 22/11/2011

26 Uscire dalla stazione di Westminster e trovarsi di fronte il Big Ben illuminato come nelle migliori cartoline o illustrazioni viste in chissà quale guida- VICKY E MANU

$27[\ldots]$ la celebre borsa di vernice col logo di Harrods dorato (l'ho ovviamente acquistata per la modica cifra di $16 £$ ) -BEATRICE ALLEGRA[Acquistiamo] la famosissima shop bag, che in Italia è tanto amata!- ALE83

28 www.ardachy.co.uk. Accessed 22/11/2011

Recibido:

Reenviado:

Aceptado:

$16 / 5 / 2011$

$6 / 3 / 2012$

$15 / 3 / 2012$

Sometido a evaluación por pares anónimos 